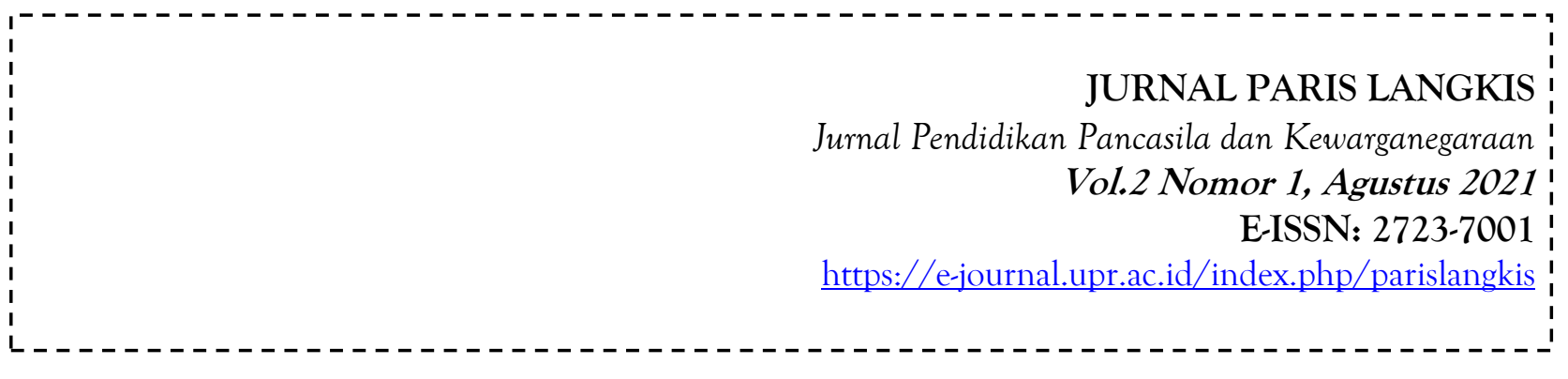

\title{
PELUANG DAN TANTANGAN PENDIDIKAN KARAKTER DI ERA PEMBELAJARAN JARAK JAUH
}

\author{
Ellectrananda Anugerah Ash-shidiqqi \\ Fakultas Hukum Universitas Slamet Riyadi \\ Email: ellectraaa@yahoo.co.id
}

\begin{abstract}
Abstrak
Tujuan dari artikel ini adalah untuk membahas peluang dan tantangan pendidikan karakter di era digital. Penelitian ini menggunakan penelitian deskriptif dan studi pustaka. Data yang diperoleh dianalisis menggunakan studi pustaka dan triangulasi. Pendidikan karakter di era digital memiliki berbagai tantangan dan peluang. Penelitian membuktikan bahwa era digital memberikan kesempatan positif untuk menerapkan pendidikan karakter. Tantangan dalam era pendidikan jarak jauh bagaimana mengajar siswa untuk memberikan materi pendidikan karakter di era digital. Pembuat kebijakan pendidikan perlu memainkan peran aktif dalam pengembangan pembelajaran karakter berkelanjutan secara digital untuk memastikan penerapan pembelajaran karakter melalui media digital yang efektif.
\end{abstract}

\section{Kata Kunci: Pendidikan Karakter, Pembelajaran Jarak Jauh}

\section{Abstract}

The purpose of this article is to discuss the opportunities and challenges of character education in the digital age. This research uses descriptive research and literature study. The data obtained were analyzed using literature study and triangulation. Character education in the digital era has various challenges and opportunities. Research proves that the digital era provides positive opportunities for implementing character education. The challenge in the era of distance education is how to teach students to provide character education material in the digital era. Education policy makers need to play an active role in the development of digital sustainable character learning to ensure the effective application of character learning through digital media.

Keyword: Character building, Long Distance Learning

\section{Paris Langkis}

Vol.2 Nomor 1, Agustus 2021 


\section{A. PENDAHULUAN}

Pendidikan karakter adalah salah satu tujuan penting dari pendidikan nasional Indonesia. Undang-Undang Nomor 20 Tahun 2003 Mengenai Sistem Pendidikan Nasional (Sisdiknas) Pasal 3 mengatakan bahwa fungsi pendidikan nasional untuk mengembangkan kemampuan dan membentuk karakter dan peradaban nasional untuk mendidik kehidupan bangsa, bertujuan untuk pengembangan potensi siswa Siapa yang percaya dan takut kepada Tuhan Yang Mahakuasa, mulia, sehat, berpengetahuan, kreatif, mandiri, dan menjadi warga negara yang demokratis dan bertanggung jawab.

Undang-undang dengan jelas mengamanatkan bahwa tujuan pendidikan tidak hanya membuat siswa intelektual secara intelektual, tetapi juga harus dapat mencetak generasi yang bersifat moral dan karakter sesuai dengan nilai-nilai, norma dan ajaran agama (kecerdasan spiritual dan emosional). Sejalan dengan tujuan sistem pendidikan nasional, pendidikan karakter sebagai kendaraan untuk menanamkan nilai-nilai moral dan karakter untuk siswa. Masyarakat sangat khawatir tentang kondisi saat ini di mana masalah moralitas karena krisis karakter merajalela terjadi di antara anak-anak dan siswa. Percampuran antara siswa, intimidasi, kekerasan terhadap guru dan orang tua, pornografi dan seolah-olah menambahkan deretan masalah panjang yang sering menabrak siswa hari ini. Melihat fenomena yang ada, implementasi pendidikan karakter untuk siswa harus tetap menjadi prioritas dalam kasus apa pun.

Selama waktu ini sekolah menjadi salah satu lembaga pendidikan yang bertanggung jawab untuk mengembangkan pengetahuan, keterampilan dan karakter siswa. Orang tua berharap dan percaya pada sekolah sebagai pusat pendidikan akademik dan pendidikan karakter. Proses pembentukan nilai karakter siswa sesuai dengan proses pembelajaran di sekolah. Namun, karena pandemi menabrak dan sekolah menutup keberlanjutan pendidikan karakter menjadi yang paling khawatir oleh orang tua.

Salah satu kunci pendidikan karakter adalah adanya role model individu berkarakter. Di sekolah, yang menjadi role model bagi peserta didik dalam menumbuhkan nilai-nilai karakter adalah sosok seorang guru. Guru yang berkarakter akan mampu menunjukkan sikap dan perilaku yang sesuai dengan norma dan nilai-nilai ajaran agama dalam kesehariannya sehingga dapat ditiru oleh peserta didik. Karena pada prinsipnya seorang anak adalah peniru. Peserta didik akan mudah mengembangkan karakternya dengan meniru atau menyaksikan perilaku gurunya.

Pembiasaan dan contoh teladan yang diberikan guru akan melahirkan peserta didik yang memiliki karakter mulia. Misalnya saja, siswa terbiasa disiplin dengan datang tepat waktu karena melihat guru-gurunya juga selalu hadir tepat waktu. Ketika mengikuti ujian, peserta didik akan berusaha jujur karena menyadari gurunya selalu mengutamakan kejujuran dalam kesehariannya. Demikian juga, mereka akan terbiasa bersikap sopan karena mencontohkan gurunya yang selalu bersikap sopan kepada siapa pun. Sayangnya, belajar dengan metode e-learning yang terhubung ke layanan Internet tidak selalu menjamin siswa aman dari pengaruh negatif dunia digital. Media digital dengan semua kebebasannya menyajikan berbagai informasi positif dan negatif. Siswa yang belum siap dengan informasi yang berat dan berlimpah, berpotensi terkena dampak negatif yang dapat mengikis karakter mereka. Terjadinya kasus-kasus intimidasi, pornografi, seksual bebas dan tindak pidana lainnya adalah dampak dari penyalahgunaan media digital di kalangan siswa.

\section{Paris Langkis}

Vol.2 Nomor 1, Agustus 2021 


\section{B. METODE PENELITIAN}

Metode deskriptif dapat ditafsirkan sebagai prosedur pemecahan masalah yang diselidiki dengan menggambarkan keadaan subjek atau objek dalam penelitian ini dapat dalam bentuk orang, lembaga, komunitas dan lainnya yang saat ini berdasarkan fakta yang terlihat atau apa adanya. Menurut Nazir (1988: 63) dalam buku sampel Metode penelitian, metode deskriptif adalah metode dalam meneliti status kelompok manusia, suatu objek, seperangkat kondisi, sistem pemikiran atau kelas peristiwa dalam menyajikan. Tujuan dari penelitian deskriptif ini adalah untuk membuat deskripsi, gambar, atau melukis secara sistematis, faktual dan akurat mengenai fakta, properti dan hubungan antarmuka yang diselidiki.

Menurut Sugiyono (2005: 21) menyatakan bahwa metode deskriptif adalah metode yang digunakan untuk menggambarkan atau menganalisis hasil penelitian tetapi tidak digunakan untuk membuat kesimpulan yang lebih luas. Menurut Whitney (1960: 160) metode deskriptif adalah pencarian fakta dengan interpretasi yang tepat. Dapat dikatakan bahwa penelitian deskriptif adalah penelitian yang berupaya menggambarkan gejala, peristiwa yang terjadi pada masalah saat ini atau aktual. Penelitian ini juga menggunakan metode studi pustaka. Studi kepustakaan merupakan teknik pengumpulan data dengan tinjauan pustaka ke perpustakaan dan pengumpulan bukubuku, bahan-bahan tertulis serta referensi-referensi yang relevan dengan penelitian yang sedang dilakukan.

\section{PEMBAHASAN}

Pendidikan karakter pada abad ke-21 lebih lanjut dapat dipahami sebagai upaya untuk menanamkan, terbiasa, dan melatih tentang praktik pemahaman, apresiasi dan praktik nilai-nilai yang terkait dengan karakter bangsa, sehingga karakternya menjadi identitasnya. , pribadinya, pola pikir, perspektif, identitas, dan serta cintanya dan bangga sebagai bangsa, dan percaya, bahwa nilainilai karakter adalah yang paling cocok untuk kehidupan bangsa Indonesia (Leluni, 2020). Nilainilai pendidikan karakter bangsa diterjemahkan dan diuraikan dari ideologi Bangsa Indonesia, Pancasila, Undang-Undang 1945, dan berbagai pemikiran dan pandangan yang disajikan oleh para pemimpin nasional Indonesia mengakui kredibilitas, kesetiaan, komitmen, cinta dan ketulusan dalam memajukan bangsa Indonesia (Alfian, 1981), hal. 104).

Karakter bangsa Indonesia dapat dijelaskan, sebagai karakter yang menyadari bahwa sifat ketuhanana merupakan nilai tertinggi, hanya dan beradab dalam komitmen. Seseorang yang memiliki karakter dari bangsa Indonesia akan menjadi negara religius, memiliki visi transendental, memprioritaskan nilai-nilai moral dan spiritual, di atas nilai-nilai yang sesaat dan profan. Dengan kemanusiaan, ia akan mencoba untuk melaksanakan misi humanisasi dan pembebasan, dan mempertahankan cara-cara di mana mereka bersifat anarkis, kekerasan dan intimidasi dalam memperjuangkan sesuatu. Dengan jiwa persatuan Indonesia. Hal tersebut akan menghormati dan menghormati keberadaan keragaman (pluralitas) dan akan menganggapnya sebagai rahmat dan kekayaan yang harus sinergis dan dengan bijak diberikan sehingga menjadi modal budaya dan budaya yang sangat mengesankan (Alfian, 1981), hal. 105).

\section{Paris Langkis}

Vol.2 Nomor 1, Agustus 2021 
Menurut Surat Edaran Menteri Pendidikan dan Kebudayaan Nomor 5 Tahun 2019 tentang Kegiatan Pertumbuhan Gagasan Nasional dalam Pengenalan Pendahuluan Lingkungan Sekolah, Pemerintah Kurikulum 2013 mempromosikan pendidikan karakter yang kemudian dapat meningkatkan kualitas proses dan pendidikan. Hasil yang diaharapkan mengarah pada pembentukan karakter dan akhlak mulia siswa sesuai dengan standar kompetensi di unit pendidikan.

Pendidikan karakter pada abad ke-21 juga terkait erat dengan upaya untuk memahami, hidup dan mempraktikkan nilai-nilai budaya bangsa Indonesia yang tumbuh dan berkembang di Indonesia, seperti nilai kerja sama timbal balik, keluarga, Kesopanan, toleransi, ramah, timbal balik dan saling menghormati, memprioritaskan musyawarah masalah pemecahan masalah yang terkait dengan penyelesaian ajaran agama dan berbagai nilai-nilai yang berkembang dan berkembang di berbagai wilayah Indonesia, yang selanjutnya disebut kearifan lokal. Berbagai nilai budaya digunakan sebagai dasar yang membentuk sikap, mentalitas, paradigma, mentalitas, perspektif dan tindakan seluruh bangsa Indonesia.

Pendidikan karakteristik nasional menghasilkan para insan dengan kesadaran historis, budaya dan peradaban (peradaban). Untuk dapat mewujudkan bangsa seperti itu, itu juga harus disertai dengan upaya untuk menciptakan karakter bangsa yang memiliki tradisi intelektual yang kuat, yaitu karakter: (1) menyukai kebenaran (tidak berusaha untuk dibenarkan); (2) kejujuran dan orisinalitas; (3) menghormati sains; dan (4) sikap kosmopolitan. Tradisi intelektual ini telah dipraktikkan oleh Ummah Islam di zaman klasik, ketika Ummah Islam muncul sebagai panduan tentang sejarah, budaya dan peradaban umat manusia hampir di seluruh dunia, dalam lebih dari tujuh abad.

Guru sebagai salah satu faktor penentu dalam pemebentukan karakter, harus memiliki inovasi dalam proses pembelajaran jarak jauh ini. Beberapa karakter pendidikan karakter yang dapat diajarkan dalam era pandemi Covid-19 ini. Pertama disiplin, disiplin yang mengacu pada kepatuhan dan ketertiban siswa dengan mematuhi aturan. Dalam situasi belajar tatap muka, siswa digunakan untuk mematuhi aturan dengan mengenakan seragam dan topi selama upacara bendera. Tiba-tiba, dalam periode pandemi Covid-19, mereka belajar di rumah tanpa seragam. Tentu saja suasananya berbeda. Kedua, Kejujuran. Ketika ujian atau pekerjaan pada tugas guru siswa cenderung mengerjakan tugas dengan serius karena guru mengawasi di kelas. Berbeda ketika mengerjakan ujian dilakukan secara daring, pengawasan terhadap siswa cenderung lemah dikarenakan beberapa faktor. Lemahnya pengawan ini telah mengundang siswa untuk membuat plagiarisme, karena tanpa pengawasan guru, bahkan jika orang tua menemani.Para guru dan orang tua pengawasan berbeda. Tiga tanggung jawab, dalam sistem tatap muka, biasanya ada kegiatan piket harian. Kegiatan ini dimaksudkan untuk melatih siswa untuk bertanggung jawab atas tugastugas mereka, berbeda ketika sistem online di mana anak-anak cenderung tidak memikirkan lingkungan sekitarnya karena mereka merasa seluruh tanggung jawab ada orang tua.

Tentu saja, tidak mudah bagi seorang guru untuk menemukan jalan keluar dari masalah elearning ini, tetapi guru tetap diperlukan untuk menemukan solusi sebagai pendidik (Zuzanti et al., 2020). Hal pertama yang dapat dilakukan guru adalah menjaga komunikasi dengan siswa, misalnya dengan teguran atau salam setiap pagi. Tujuan dari kegiatan ini adalah untuk menjaga

\section{Paris Langkis}

Vol.2 Nomor 1, Agustus 2021 
antusiasme dan mengingatkan bahwa guru selalu memonitor dan menjadi contoh bahwa sikap ramah sangat penting. Kedua, tingkatkan disiplin. Dapat diterapkan ketika guru melakukan pembelajaran, biasanya waktu pembelajaran sudah terjadwal, guru dapat melakukan pembelajaran sesuai waktu yang telah ditentukan tanpa mengurangi ataupun menambah jam mata pelajaran.

Tanggung jawab, rasa tanggung jawab akan terjadi jika guru dan siswa memahami pekerjaan rumah mereka, guru dan siswa mengikutinya. Dengan demikian, mereka mampu menyelesaikan tugas masing-masing secara independen. Tanggung jawab ini tidak hanya terbatas pada penyelesaian tugas sekolah, siswa juga bertanggung jawab atas posisi mereka di rumah. Misalnya, bagaimana peran dan tanggung jawab sebagai saudara yang menjaga saudara perempuan mereka, peran adik laki-laki yang mematuhi kakannya, peran ayah dan ibu yang mendidik anakanaknya. Itu belum selesai di sana, tanggung jawab di lingkungan sekitarnya juga sangat penting. Bagaimana anggota komunitas.

Guru dan orang tua harus memiliki tujuan yang sama untuk pendidikan yang diharapkan untuk dicapai. Guru memberi pengajaran dan orang tua untuk memahaminya, sebagai guru untuk memberikan pengajaran dan orang tua untuk melakukan contoh aktif. Tentu saja, tujuannya agar ssiwa lebih antusias untuk memakannya. Tidak hanya itu, pengawasan orang tua untuk anak-anak menggunakan teknologi juga sangat penting. Misalnya, bagaimana mengatur waktu ketika menggunakan ponsel saat belajar dan membaca sehingga anak-anak tidak salah fokus pada ponsel untuk kegiatan belajar.

Model Pendidikan yang utama adalah keberadaan model individu. Di sekolah, model siswa yang tumbuh nilai karakter adalah sosok seorang guru. Karakter atau sikap seorang guru akan dapat menunjukkan sikap dan perilaku yang memenuhi standar dan nilai-nilai ajaran agama dalam kehidupan sehari-hari mereka sehingga mereka dapat ditiru oleh siswa. Karena, pada prinsipnya, seorang anak adalah salinan. Siswa akan dengan mudah mengembangkan karakter mereka dengan meniru atau melihat perilaku mereka dari guru mereka.

Contoh-contoh yang akan diberikan guru kepada siswa yang memiliki karakter yang mulia. Misalnya, siswa terbiasa dengan disiplin ketika mereka datang ke waktu karena mereka melihat bahwa gurunya juga selalu hadir tepat waktu. Ketika mengerjakan menghabiskan ujian, para siswa akan berusaha jujur karena mereka menyadari bahwa guru selalu menghiasi kejujuran dalam kehidupan sehari-hari. Demikian pula, mereka akan terbiasa bersikap sopan karena mereka menggambarkan guru mereka selalu sopan kepada siapa pun.

Sayangnya, belajar dengan metode pembelajaran online yang terkait dengan layanan Internet tidak selalu menjamin siswa yang aman untuk pengaruh negatif dari dunia digital. Media digital dengan semua kebebasan memiliki berbagai informasi positif dan negatif. Siswa yang belum siap dengan informasi yang berat dan berlimpah, berpotensi terkena kandungan negatif yang dapat mengikis karakter mereka. Terjadinya kasus intimidasi, pornografi, asosiasi bebas dan tindakan kriminal lainnya adalah dampak penyalahgunaan media digital di kalangan siswa.

Teknologi negatif dan pengaruh Internet lainnya memberikan ketergantungan pada penggunanya. Semuanya tersedia di internet yang membuat orang merasa bahwa beberapa siswa

\section{Paris Langkis}

Vol.2 Nomor 1, Agustus 2021 
merasa di rumah yang gigih. Ada kekhawatiran terhadap kondisi seperti itu untuk melatih karakter siswa untuk dikonsumsi, kreativitas minimal, malas berinovasi dan ingin mendapatkan sesuatu secara instan. Efek ketergantungan Internet juga membuat siswa malas berpikir kurang bertanggung jawab, sehingga tidak optimal untuk menyelesaikan tugas-tugas smereka.

Praktik pendidikan di era digital membutuhkan inovasi dan kreasi berkelanjutan sehingga guru dan siswa tidak mudah mengetahui kejenuhan dan kebosanan. Guru dan orang tua jangan menafsirkan pembelajaran online yang menawarkan siswa siswa untuk menjawabnya. Jika ini terjadi, pelepasan pembelajaran dan karakter akan berhenti dalam slogan tanpa pernah mengalami semangat. Akibatnya, pembelajaran tidak pernah mencapai tujuan yang diinginkan sesuai kurikulum

Namun, selain beberapa kendala yang muncul, beberapa kebijaksanaan dapat diperoleh dari pandemi Covid-19 tanpa menyadarinya. Dengan sistem pembelajaran jarak jauh, di mana siswa melakukan banyak kegiatan di rumah untuk memfasilitasi pengawasan anak-anak mereka. Selain itu, dalam hal kreativitas para pendidik dan siswa dalam sistem pembelajaran jarak jauh, diperlukan untuk menjadi kreatif. Misalnya, bukan beberapa pendidik membuat materi pembelajaran disajikan dalam bentuk video pembelajaran.

\section{KESIMPULAN}

Sejah pandemi mewabah, ada lebih dari satu tahun program pembelajaran rumah (BDR). Selama siswa juga hanya mengenal informasi dari gadget dan dunia digital yang tidak selalu aman untuk pengembangan karakter mereka. Hal ini akan menjadi suatu hal yang menakutkan dan pembelajaran on-line berlanjut, siswa akan terbiasa dengan orang asing yang kurang mendidik Sayangnya, mereka akan dapat kehilangan banyak waktu dengan pendidikan karakter yang nilainya sangat berharga sebagai ketentuan untuk menjalani kehidupan.

Oleh karena itu, sudah waktunya bagi para pemangku kepentingan kepada dunia pendidikan untuk merumuskan kebijakan terbaik dengan menanggapi tantangan pendidikan kepribadian selama pandemi. Masyarakat tentu tidak mengharapkan sosok pemilik bagsa ke depan menghilang dari siswa untuk menjadi bagian dari kebiasaan baru dalam hidup mereka. Jika nanti, kita tidak lagi aneh melihat generasi muda kehilangan karakter positif karena sistem pembelajaran online yang mengutamakan transfer pengetahuan terlepas dari menanam nilai-nilai dan karakter moral. Bangsa yang hebat adalah negara yang memiliki generasi yang memiliki karakter kepribadian yang baik, tidak hanya cerdas dalam sains. Pandemi ini bukanlah hambatan kita untuk menciptakan generasi muda, berbudi luhur dan karakter yang baik.

\section{DAFTAR PUSTAKA}

Abdul Ghofur, Wahyono, Strategi Qur'ani Mengenai Diri Sendiri dan Meraih Kebahagiaan Hidup, (Yogyakarta:Belukar Budaya, 2004), cet. I.

Alfian, Politik, Kebudayaan dan Manusia Indonesia, (Jakarta:LP3ES, 1981), cet. II.

Arief, Armai, Reformulasi Pendidikan Islam, (Ciputat:CRSD Press, 2007), cet. II.

\section{Paris Langkis}

Vol.2 Nomor 1, Agustus 2021 
Asmani, Jamal Ma'ruf, Tips Efektif Menjadi Sekolah Berstandar Nasional dan Internasional, (Jogjakarta:Hamoni, 2011), cet. I.

Bush, Tony and Les Bell, The Principles and Practice of Educational Management, ( London:A. SAGE Publications Company, 2002), First Published.

Fatah, Abdul, Budaya Toleransi dalam Pembelajaran Pendidikan Agama Islam, (Jakarta:Young Progressive Muslim, 2012), cet. I.

Fuller, Graham E., A World Without Islam, (New York, Boston, London:Little, Brown and Company, 2010), First Edition.

Gulen, Muhammad Fethullah, Islam Rahmatan Lil Alamin, (Jakarta:Republika Penerbit, 2011), cet. I.

......., Qadar di Tangan Siapakah Takdir atas Diri Kita, (Jakarta:Republik Penerbit, 2011), cet. I.

..m...., Cahaya Al-Qur'an Bagi Seluruh Makhluk, Tafsir Ayat-ayat Pilihan Sesuai Kondisi Dunia Saat Ini, (Jakarta:Republika, 2011), cet. I.

......., Dakwah Jalan Terbaik dalam Berfikir dan Menyikapi Hidup, (Jakarta:Republika, 2011), cet. I.

Hadad, Ismid, (ed.), Kebudayaan Politik dan Keadilan Sosial, (Jakarta:LP3ES, 1981), cet. II.

Hasan, Muhammad Tholchah, Islam dalam Perspektif Sosio Kultural, (Jakarta:Lantabora Press, 2000).

Heriyanto, Husain, Menggali Nalar Saintifik Peradaban Islam, (Bandung:Mizan, 2011), cet. I.

Hasbullah, Moeflich, Sejarah Intelektual Islam di Indonesia, (Bandung:Pustaka Setia, 2012), cet. I.

Ismail, Faisal, Pijar-pijar Islam Pergumulan Kultur dan Struktur, (Yogyakarta:Lembaga Studi Filsafat Islam, 2002), cet. I.

Kamaluddin, Laode M., On Islamic Civilization Menyalakan Kembali Lentera Peradaban Islam Yang Sempat Padam, (Jakarta:Unissula Republikata, 2010), cet. I.

Khan, Muhammad Waheeduddin, Muhammad Nabi untuk Semua, (terj.) dari buku Muhammad A Prophet for All Humanities, (Jakarta:Bulan Bintang, 1998), cet. I.

Koesoema A., Doni, Pendidikan Karakter, Strategi Mendidik Anak di Zaman Global, (Jakarta:Gramedia, 2007), cet. I

Muhaimin, Nuansa Baru Pendidikan Islam Mengurai Benang Kusut Pendidikan Islam, (Jakarta:RajaGrafindo Persada, 2006), cet. I.

Mahmud, Ali Abdul Halim, Akhlak Mulia, (terj.) Abdul Hayyie al-Kattani, (Jakarta:Gema Insani Press, 1415 H./1995), cet. I.

Mulyasa, H.E., Manajemen Pendidikan Karakter, (Jakarta:Bumi Aksara, 2012), cet. II.

Muslich, Masnur, Pendidikan Karakter Menjawab Tantangan Krisis Multidimensional, (Jakarta:Bumi Aksara, 2011), cet. I.

Muthahhari, Ayatullah Murthada, Pengantar Epistimologi Islam, (Jakarta:Shadra Press, 2010), cet. I.

Nata, Abuddin, Akhlak/Tasawuf, (Jakarta:RajaGrafindo Persada, 2005), cet. I.

...m..., Sejarah Sosial Intelektual Islam dan Institusi Pendidikannya, (Jakarta:RajaGrafindo Persadam 2012), cet. I.

Mas'ud, Abdurrahman, Intelektual Pesantren, Perhelatan Agama dan Tradisi, (Yogyakarta:LkiS Yogyakarta, 2004), cet. I.

\section{Paris Langkis}

Vol.2 Nomor 1, Agustus 2021 
Al-Qardaw, Muhammad Yusuf, Iman dan Kehidupan, (terj.)H.A.R.Fakhruddin, dari buku al-Iman wa al-Hayat, (Jakarta:Bulan Bintang, 1986), cet. I.

Rahamn, Yusuf, (ed.), Islam and Society in Contemporary Indonesia, (Jakarta:Interdisciplinary Islamic Studies Program Faculty of Graduate Studies, Syarif Hidayatullah State Islamic University Jakarta, 2006), First Edition.

Ramzy, A. Naufal (ed.), Islam dan Transformasi Sosial Budaya, (Jakarta:CV Deviri Ganan, 1993), cet. I.

Sucipto, Hery, Islam Madzah Tengah:Persembahan 70 Tahun Tarmizi Taher, (Jakarta:Grafindo Khazanah Ilmu, 2007), cet. I.

Tasmara, Toto, Etos Kerja Pribadi Muslim, (Yogyakarta:Dana Bhakti Wakaf, 1995), cet. I.

Tholhah, Imam, ect, (Team of Reviewers), The Strategic Role of Religious Education in The Development $f$ Culture of Peacem, (Jakarta: Centre for Research and Development of Religious Education and Religion: Ministry of Religious Affairs of the Republik Indonesia, 2012), First Edition.

Triwibowo, Darmawan, Gerakan Sosial Wahana Civil Society bagi Demokrasi, (Jakarta:LP3ES, 2006), cet. I.

Young, Grogory G, Membaca Kepribadian Orang, (Jogjakarta:Thingk, 2008), cet. X.

Wahid, Abdurrahman (Gus Dur), Islamku, Islam Anda, Islam Kita:Agama Masyakara Negara Demokrasi, (Jakarta:The Wahid Institute, 2006), cet. I.

......, Islam Kosmopolitan, (Jakarta:The Wahid Institute, 2008), cet. I.

Walujo, Imam dan Kons, Dialog:Indonesia Kini dan Esok, (Jakarta:Lembaga Penunjang Pembangunan Nasional, (Jakarta:Leppenas, 1980), cet. I.

Zamroni, Pendidikan Demokrasi pada Masyarakat Multikultural, (Yogyakarta:Gavin Kalam Utama, 2011), cet. I.

Zubaedi, Desin Pendidikan Karakter Konsepsi dan Aplikasinya dalam Lembaga Pendidikan, (Jakarta:Prenada Media, 2011), cet. I.

\section{Paris Langkis}

Vol.2 Nomor 1, Agustus 2021 